USBAD Uluslararası Sosyal Bilimler Akademi Dergisi -

International Journal of Social Sciences Academy, YIl 2, Year

2, Sayı 4, Issue 4, Aralık 2020, December 2020.

e Issn: 2687-2641

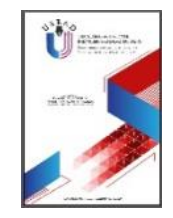

\title{
BMGK DAİMİ ÜYELERİNİN SURİYE KRİZİNE YAKLAŞIMI: UYUŞMAYAN TALEPLER VE ÇATIŞAN ÇÖZÜMLER*
}

THE APPROACHES OF GREAT POWERS TO THE SYRIAN CRISIS: INCOMPATIBLE DEMANDS AND CONFLICTING SOLUTIONS

\author{
Mehmet Turan ÇAĞLAR \\ Dr. Ar. Gör., Uluslararası İlişkiler, Uluslararası İlişkiler, FMV Işık Üniversitesi, \\ İstanbul/Türkiye. \\ Dr. Res. Asst., International Relations, International Relations, FMV Işık \\ University, \\ Istanbul/Turkey. \\ m.turan.caglar@gmail.com \\ ORCİD ID: 0000-0003-1906-1471

\section{Makale bilgisi | Article Information} \\ DOI: $10.47994 /$ usbad.784102 \\ Makale Türü / Article Type: Araştırma Makalesi / Research Article \\ Geliş Tarihi / Date Received: 22.08.2020 \\ Kabul Tarihi / Date Accepted: 10.12.2020 \\ Yayın Tarihi / Date Published: 20.12.2020 \\ Yayın Sezonu / Pub Date Season: Aralık / December
}

Bu Makaleye Atıf İçin / To Cite This Article: Çağlar, M. T. (2020). BMGK Daimi Üyelerinin Suriye Krizine Yaklaşımı: Uyuşmayan Talepler ve Çatışan Çözümler. USBAD Uluslararası Sosyal Bilimler Akademi Dergisi 2(4), 968-999.

Intihal: Bu makale intihal.net yazılımınca taranmıştır. İntihal tespit edilmemiştir. Plagiarism: This article has been scanned by intihal.net. No plagiarism detected.

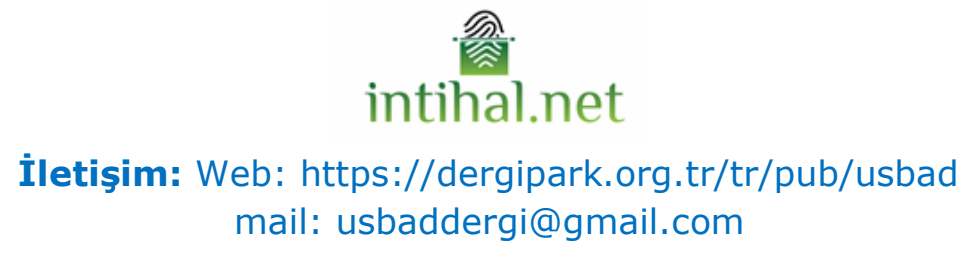

* Bu makale TUBITAK 1001 Projesi (Proje No: 112K172) desteğiyle hazırlanmıştır. 
Öz: Mart 2011'de ülke içerisinde gösterilerle başlayan Suriye krizi, BMGK'nın daimi üyelerinin krize yaklaşımından etkilenmiştir. BM'de veto yetkisine sahip bu devletler, krize kısa zaman içerisinde müdahil olmuş fakat bu aktörlerin farklı hedefleri, krizin çözümünü engellerken hayata geçirdikleri önlemler, birbirlerini etkisizleştirmiştir. Ayrıca tarafların yaklaşımları doğrultusunda devreye soktuğu önlemler, BMGK'nın etkinliğini sınırlandırmıştır. ABD, İngiltere ve Fransa, Suriye krizinin kaynağını Suriye yönetiminin yöntemleri olarak görmüş ve krizin çözümünü Suriye'de yönetimin değişmesi olarak belirlemiştir. Diğer taraftan Rusya ve Çin, krizin kaynağını Suriye yönetiminin yanında ülke içinde şiddet uygulayan diğer aktörler olarak görmüş ve dışarıdan herhangi bir müdahaleye karşı çıkmıştır. Daimi üyelerin krize yaklaşımları taraflar arası bir denge oluştursa da zaman içerisinde ABD, İngiltere ve Fransa'nın kriz bağlamında önceliklerinin değişmesi, Rusya'nın Suriye iç savaşına katılması ve BMGK'nın Rusya ve Çin'in siyasal çözüm önerilerini desteklemesiyle birlikte Suriye krizinin tarafları arasındaki denge bozulmuş ve Çin ve Rusya'nın krize yaklaşımları ön plana çıkmıştır. Bu bağlamda bu çalışmayla BMGK'nın daimi üyelerinin Suriye krizine etkilerinin neler olduğu gösterilecektir. Ayrıca çalışmada bu aktörlerin hangi stratejileri devreye soktuğu ve bu stratejilerin küresel örgüt üzerindeki etkileri analiz edilecektir. Bu analiz için daimi üyelerin açıklamaları ve hayata geçirdiği siyasalar gösterilip BMGK'da Suriye kriziyle ilgili alınan kararlar ve bu kararların krize etkileri incelenecektir.

Anahtar Kelimeler: Suriye Krizi, Uluslararası Kriz, Birleşmiş Milletler Güvenlik Konseyi, ABD, Rusya Federasyonu

Abstract: The Syrian crisis, which started in March 2011 with mass demonstrations, has been affected by the conflicting approaches of the permanent members of the UNSC. The UNSC veto powers have intervened in the crisis in a short time, but their different objectives have prevented any long-term solutions, and their measures have neutralized the others' measures. Furthermore, conflicting demands of the parties have limited the effectiveness of the UNSC. The USA, France, and the UK considered the source of the Syrian crisis as the policies of the Syrian administration, and they determined the solution as the change of the Syrian administration. On the other hand, Russia and China have seen the source of the crisis as the violence of other actors besides the Syrian administration's policies and opposed any foreign intervention in the crisis. Although the permanent members' conflicting approaches have created a kind of balance between the parties, China and Russia's approaches to the crisis has begun to come to the fore after Russia's direct intervention in the Syrian civil war, the change in the priorities of the USA, Britain, and France in the context of the crisis, and the support of the UNSC to Russia and China's initiatives in terms of a political solution. In this context, this article will show the effects of the UNSC veto powers on the Syrian crisis. Moreover, their strategies about the crisis and 
the effects of these strategies on the global organization will be analyzed. For this analysis, the permanent members' declarations and implemented policies during the Syrian crisis, and the effects of UNSC resolutions on the crisis will be examined.

Keywords: Syrian Crisis, International Crisis, United Nations Security Council, USA, Russian Federation

\section{GİRİŞ}

Arap Baharı çerçevesinde Mart 2011'de barışçıl gösterilerle başlayan Suriye krizi, ${ }^{*}$ kısa zaman içerisinde karşılıklı çatışmalara ve iç savaşa dönüşmüştür. Krizin Suriye içerisinde çözülememesin etkisiyle, bölgesel ve uluslararası aktörler, krize müdahil olmaya başlamış ve kriz üzerinden karşı karşıya gelmiştir. Bölgedeki aktörlerin Suriye krizine farklı araçlarla müdahil olması, krizi Orta Doğu alt sistemine taşırken uluslararası güçlerin müdahaleleriyle Suriye krizi uluslararasılaşmıştır. Birleşmiş Milletler Güvenlik Konseyi'nin (BMGK) daimi üyelerinin Suriye krizinin kaynağına ve çözümüne dair farklı yaklaşımlara sahip olmasıysa uluslararası düzlemde Suriye krizinin çözümünü engelleyen önemli etkenlerden biri olmuştur.

Bu bilgiler ışığında çalışmanın temel sorusu, "uluslararası düzlemde Suriye krizinin neden çözülemediğidir?" Bu temel soruya cevap aranırken BMGK'nın daimi üyelerinin krizin çözümü için ortaya koyduğu taleplerin ve hayata geçirdikleri önlemlerin neler olduğu cevap aranacak diğer önemli sorulardır. Bu yolla ayrıca bu aktörlerin talep ve önlemlerinin BMGK üzerindeki etkilerinin neler olduğu gösterilerek BMGK'nın alamadığı ve alabildiği kararlarının Suriye krizi üzerindeki etkileri incelenecektir.

Çalışmanın temel argümanı, uluslararası krizlerin çözümü açısından önemli olan BMGK'nın daimi üyelerinin farklı taleplerinden etkilendiği, daimi üyelerin Suriye krizi özelinde iki farklı yaklaşım sergilediği, farklı taleplerde bulunduğu ve bu taleplerin krizin çözümünü engellediğidir. Bu aktörlerin kriz açısından devreye soktuğu araçlar, birbiriyle çatışmış ve aktörler, krizin çözümsüzlüğü konusunda birbirlerini suçlamıştır. Daimi üyelerin farklı talep ve önlemleri, BM'nin

\footnotetext{
* Suriye krizi kendi içerisinde çok sayıda sorunu barındıran bir krizdir. Suriye iç savaşının dışında kimyasal silah kullanımı, uluslararası terörizm ve aşırılık, yerel insani krizler, Suriyeli mülteciler konusu, Suriye'nin komşularının sınır güvenlikleri, silahlı devlet dışı aktörlerin oluşturduğu tehditler gibi çok sayıda sorun, Suriye krizinin bir parçası olarak görülmektedir. Fakat bu sorunların birçoğunun çözümü, Suriye iç savaşının sonlandırılması olarak görülmüştür. Bu yüzden çalışma boyunca Suriye krizi, Suriye iç savaşı bağlamında incelenecektir.
} 
etkisini sınırlandırmış ve küresel örgüt de süreç içerisinde krizin çözümüne istenilen katkıda bulunamamıştır. BMGK'da daimi üyelerin asgari taleplerinin karşılandığı durumlarda alınan kararlar ise Suriye krizini sonlandırmasa da Suriye kriziyle ilinti konular için önemli referans noktaları olmuştur.

Bu temel sorulara cevap bulmak için çalışma dört ana bölümden oluşmaktadır. Birinci bölümde küresel örgütün hangi şartlar altında krizlere müdahalelerinin arttığı gösterilecek ve daimi üyelerinin Suriye krizine neden farklı yaklaşım sergiledikleri kısaca belirtilecektir. İkinci bölümde Suriye krizinin kaynağını Suriye yönetiminin siyasaları olarak gören $A B D$, İngiltere, Fransa ve Avrupa Birliği'nin (AB) hayata geçirdiği önlemler gösterilmeye çalışılacaktır. Üçüncü bölümde Suriye krizine farklı yaklaşım sergileyen ve Suriye'de silahlı devlet dışı aktörlerin uyguladıkları şiddete dikkat çeken Çin ve Rusya'nın devreye soktuğu araçlar gösterilecektir. BMGK'da veto yetkisine sahip devletlerin Suriye krizine farklı yaklaşım sergilemeleri, uluslararası düzlemde ortak bir siyasanın oluşmasını engellese de dördüncü bölümde BMGK'da Suriye kriziyle ilgili alınan kararlar ve bu kararların Suriye krizi üzerindeki etkileri gösterilecektir. Bu bölümde ayrıca daimi üyelerin Suriye krizine son dönemdeki yaklaşımları incelenecektir.

\section{ULUSLARARASI KRİZLERDE BM VE BMGK}

Uluslararası krizlerin yönetimi ve çözümü açısından küresel örgütün rolü önemli bir değişken olarak kabul edilmektedir. Üçüncü aktör müdahalesi* olarak görülen küresel örgütün krizlere müdahalesinde gündem belirleme gibi doğrudan veya tarafların pazarlık etmelerine yardımcı olma gibi kolaylaştırıcı etkide bulunması beklenmektedir (Brecher ve Wilkenfeld, 1997: 849-850). Küresel örgütün kolaylaştırıcı rolünün yanında özellikle Soğuk Savaş sonrası dönemde iç savaş gibi gelişmelerde krizin aktörlerine karşı sınırlandırıcı tedbirler getirdiği de görülmektedir. Bu sınırlandırıcı tedbirler, Koruma Sorumluluğu prensibinde olduğu gibi askeri müdahaleye kadar varabilmektedir. Tarihsel olarak şiddetin yoğun olduğu krizlerde küresel örgütün ve BMGK'nın müdahaleleri artmaktadır. Ayrıca taraflar arası gerilimin yüksek olduğu, krize taraf olan aktör sayısının fazla olduğu ve büyük güçlerin aktif olduğu krizlere küresel örgüt ve BMGK

\footnotetext{
* Üçüncü aktör müdahalesinde üçüncü aktörün doğrudan krizin tarafı olmaması gerekir. Bu yüzden BMGK'nın daimi üyeleri, zaman içerisinde krizin tarafı haline geldiği için büyük güçlerin Suriye'deki gelişmelere müdahaleleri, üçüncü aktör müdahalesi çerçevesinde görülmemelidir.
} 
daha fazla müdahil olmaktadır (Brecher ve Wilkenfeld, 1997: 856862). Benzer bir şekilde uzun bir döneme yayılan krizlere BM ve BMGK'nın müdahil olması daha olasıdır (DeRouen Jr, 2003: 259). Bu yüzden BM ve BMGK'nın Suriye krizi ve ilintili konulardaki müdahaleleri, küresel örgütün uluslararası krizlere müdahalelerindeki örüntüsüne benzerlik göstermektedir. Bu benzerlik doğrultusunda BMGK, Mart 2011-Temmuz 2020 arası Suriye krizi ve ilintili konularla ilgili 41 karar almış ve Suriye krizi, BMGK'nın en önemli gündem maddelerinden biri olmuştur.

Her ne kadar BMGK, önceki uluslararası krizlerde küresel örgütlerin etkinliğine benzer bir şekilde Suriye krizinde aktif rol oynasa da BMGK'nın aldığı onca karar, Suriye krizini sonlandıramamıştır. BMGK'nın krizi sonlandırmadaki etkisizliği ise daimi üyelerinin Suriye krizine yaklaşımlarındaki farklılıklardan kaynaklanmıştır. ABD, İngiltere, Fransa, Çin ve Rusya'nın krizin kaynağı ve çözümü konusundaki farklı yaklaşımları, BMGK'da krizin taraflarına karşı sert tedbirlerin ve önemli sınırlandırıcı veya teşvik edici önemlerin alınmasını engellemiştir. Bu yüzden BMGK, Suriye krizinde aktif ama görece etkisiz bir aktör olmuştur. Aktifliği, Suriye krizinin uluslararası siyasette yarattığı etkiden kaynaklanırken, görece etkisizliği, daimi üyelerin uyuşmayan taleplerinden kaynaklanmıştır.

Daimi üyelerin krize farklı yaklaşım sergilemeleri ise hem bu üyelerin Suriye'yle olan tarihsel ilişkilerinden hem de Arap Baharı sürecinde yaşananlardan kaynaklanmaktadır. ABD adına özellikle 2003 Irak Savaşı'yla birlikte Suriye yönetimiyle ilişkiler giderek kötüleşmiş ve Suriye yönetiminin faaliyetleri; ABD'nin ulusal güvenlik, dış politika ve ekonomisine yönelik tehdit olarak tanımlanmıştır. Bu bağlamda örneğin 2004 yılında ABD; Suriye'nin terörizmi desteklediği, Lübnan'ı işgal ettiği, kitle imha silahlarına sahip olduğu ve $A B D$ 'nin ve uluslararası toplumun Irak'taki çabalarını baltaladığı gerekçeleriyle Suriye yönetimine karşı yaptırım uygulamaya başlamıştır (U.S. Department of the Treasury, 2 Ağustos 2013). Zaman içerisinde taraflar arasındaki ilişkilerde dalgalanmalar olsa da Suriye yönetimi, genel hatlarıyla ABD tarafından tehdit olarak görülmeye devam etmiştir. Avrupalı aktörlerin Suriye yönetimine karşı tavırları, ABD kadar sert olmasa da Suriye yönetiminin siyasaları, 2011 öncesi dönemde de İngiltere ve Fransa'nın eleştirilerine maruz kalmıştır. Özellikle Suriye'nin Lübnan'da mevcudiyetinin devam etmesi, Lübnan Başbakanı Refik Hariri'nin öldürülmesi, Suriye yönetiminin İran ve 
Hizbullah'la ilişkileri ve insan hakları ihlalleri (Embassy of France in Washington, D.C., 4 Temmuz 2010; Foreign and Commonwealth Office, 5 Kasım 2010), Fransa ve İngiltere'nin 2011 öncesinde Suriye yönetimine karşı yönelttikleri önemli eleştiriler olmuştur.

$A B D$, İngiltere ve Fransa örneklerinde olduğu gibi Rusya ve Çin'in Suriye yönetimiyle ilişkileri ve Arap Baharı'nda yaşananlar, bu iki büyük gücün Suriye krizine yaklaşımını etkileyen önemli faktörlerdir. Rusya'nın Suriye'yle olan tarihsel ilişkileri, Rusya'nın tavrını belirlerken, Çin açısından geleneksel egemenlik anlayışının aşındırılmasının engellenmesi önemli olmuştur. Bu iki aktör için ayrıca 2011 yılında BMGK kararıyla NATO'nun Libya'ya düzenlediği askeri operasyon önemli bir referans noktası olmuştur (The Ministry of Foreign Affairs of the Russian Federation, 2 Haziran 2011). Çin ve Rusya, Suriye'de Libya'ya benzer bir sürecin yaşanmasını engellemek için daha temkinli davranmış ve Suriye'ye olası bir operasyonun önünü açabilecek tüm girişimleri reddederken "küresel istikrarı" korumak için Suriye krizinde birlikte çalıştıklarını duyurmuştur (The State Council: The People's Republic of China, 5 Ocak 2020). Bir başka ifadeyle, daimi üyelerin Suriye'yle olan tarihsel ilişkileri ve Arap Baharı sürecinde yaşanan güncel gelişmeler, Suriye krizi adına BMGK'da iki farklı kutbun ortaya çıkmasındaki en önemli sebepler olmuştur. Süreç içerisinde krizin dönüşümünü etkileyen en önemli politikalar ise $A B D$ ve Rusya tarafından hayata geçirilmiştir.

\section{ABD, INGÍLTERE VE FRANSA'NIN HAYATA GEÇİRDİĞİ ÖNLEMLER}

Mart 2011 sonrası ABD, İngiltere ve Fransa, Suriye krizinin ve ülke içerisindeki şiddetin kaynağını, Suriye yönetiminin hayata geçirdiği sert güvenlik önlemleri olarak görmüş ve krizin başladığı ilk aylarda Suriye yönetiminden şiddeti sona erdirmesini ve reformları gecikmeden hayata geçirmesini talep etmiştir. Bu talepler doğrultusunda ABD Dışişleri Bakanlığı (23 Mart 2011), Suriye'deki çatışmaların ilk günlerinde "Suriye hükümetinin, halkının evrensel haklarını özgürce kullanmasını şiddet, yıldırma ve keyfi tutuklamalarla engellemesinden derin kaygı duyduğunu" açıklarken, Fransa Cumhurbaşkanı, "Suriye'deki göstericilere ve sivillere karşı uygulanan şiddetten rahatsız olduklarını" belirtmiştir. İngiltere Dışişleri Bakanı da (25 Mart 2011) benzer bir şekilde "Suriye hükümetini halkın barışçıl protesto etme 
hakkına saygı duymaya" çağırmış ve reformların hayata geçirilmesini talep etmiştir.

Suriye'deki çatışmaların şiddetlenerek devam etmesi sonucu ABD, İngiltere ve Fransa'nın Suriye yönetimine karşı tavrı daha da sertleşmiş ve 18 Ağustos 2011 tarihinde bu aktörlerin Suriye krizine yaklaşımında önemli bir dönüşüm yaşanmıştır. 18 Ağustos 2011'de İngiltere ve Fransa, Almanya'yla birlikte Cumhurbaşkanı Esad'ın meşruiyetini kaybettiğini ve iktidardan çekilmesi gerektiğini belirtirken (Foreign ve Commonwealth Office, 18 Ağustos 2011), aynı gün Obama yönetimi de Beşşar Esad'ın iktidardan çekilmesini talep etmiştir (The White House, 18 Ağustos 2011). Bu tarihinden sonra ABD, İngiltere ve Fransa için krizin çözümü, Suriye yönetiminin değişmesi olmuş ve hayata geçirdikleri önlemler, Suriye'de yönetim değişikliğini hedeflemiştir.

\subsection{Suriye Yönetimine Karşı Yaptırımlar}

$A B D$, Fransa ve İngiltere, 18 Ağustos öncesi taleplerini kabul ettirmek, 18 Ağustos sonrasıysa Suriye'de siyasal dönüşümü sağlamak için Suriye yönetimine karşı öncelikle ekonomik ve diplomatik yaptırımlar uygulamıştır. Suriye içerisinde artan şiddetin de etkilediği yaptırım kararları, sadece Suriye'nin yönetim kademesine karşı olmamış, Suriye yönetimine yakın iş insanları, kurumlar ve hatta Suriye krizindeki rolleri gerekçesiyle Rusya, İran ve Hizbullah'a karşı da olmuştur. ABD, İngiltere ve Fransa'nın Suriye'ye karşı uyguladığı yaptırımların başında diplomatik yaptırımlar gelmektedir. Özellikle ülke içerisinde şiddetin tırmandığı dönemlerde $A B D$, İngiltere ve Fransa, Suriye'ye karşı diplomatik yaptırım uygulayarak taleplerini kabul ettirmeye çalışmıştır. Bu bağlamda Şubat 2012'de ABD (U.S. Department of State, 6 Şubat 2012), Mart 2012'de Fransa ve İngiltere (Foreign ve Commonwealth Office, 1 Mart 2012), Suriye'deki büyükelçiliklerini kapatırken, Suriye yönetimiyle olan diplomatik ilişkilerini askıya almıştır. Haziran 2012'de ise Hule'de yaşanan şiddet olaylarından sonra içlerinde ABD, Fransa ve İngiltere'nin bulunduğu 11 ülke, ${ }^{*}$ ülkelerindeki Suriyeli diplomatları sınır dışı etmiştir (MacFarquhar, 29 Mayıs 2012).

$A B D$ ve $A B$ üzerinden İngiltere ve Fransa'nın Suriye yönetimine karşı uyguladığı en geniş önlemlerden bir diğeri, Suriye'deki

\footnotetext{
* ABD, Fransa ve İngiltere dışında Suriyeli diplomatları sınır dışı eden ülkeler; Avustralya, Kanada, Almanya, İspanya, Italya, Bulgaristan, Belçika ve Hollanda'dır. Bu ülkelere bir gün sonra Japonya ve Türkiye katıımıştır.
} 
çatışmalarla ilişkili birey ve kurumlara uygulanan ekonomik yaptırımlardır. $A B$ ve $A B D$, Nisan ayının sonunda ekonomik yaptırımlar için harekete geçmiş ve bu tarihten sonra ekonomik yaptırımlar, bu aktörlerin en temel stratejilerinden biri olmuştur. AB, Mayıs 2011'de 13 kişiye yaptırım uygulama kararı alarak, Suriye krizi bağlamında ilk kez yaptırım uygulamaya başlamıştır. Cumhuriyet muhafızları komutanı Mahir Esad, İstihbarat başkanı Ali Memluk, Deraa ilinin eski güvenlik başkanı Atıf Necip gibi isimler, göstericilere şiddet uyguladıkları, Fevvaz Esad ve Münzir Esad, Şebbiha milislerinin bir parçası olarak sivillere karşı baskı uyguladıkları ve Suriyeli iş adamı Rami Mahluf, 'rejimin' uyguladığı şiddeti finanse ettiği gerekçeleriyle yaptırımlara maruz kalmıştır (European Union, 10 Mayıs 2011). Aynı ay içerisinde içlerinde Beşşar Esad olmak üzere yaptırım uygulanan kişilerin listesi genişletilmiştir (European Union, 1 Haziran 2013). Temmuz ve Ağustos 2011 'de güvenlik güçlerinin Hama'da uyguladığı yoğun şiddeti sonrası $A B$, yeni kişilere yaptırım kararı alırken, ilerleyen yıllarda Suriye'deki şiddet olaylarında rol oynadığı gerekçesiyle yeni isimlere yaptırım uygulamaya devam etmiştir. $A B$ açısından bireysel yaptırımlar, krizle ilgili en temel önlemlerden biri olmuş ve AB'nin Ocak 2019'a kadar yaptırım uyguladığı kişi sayısı, 274'e ulaşmıştır (European Union, 21 Ocak 2019).

$A B$, ayrıca Suriyeli şirket ve kurumlara yönelik devreye soktuğu yaptırımlarla ekonomik yaptırımlarını genişletmiştir. Haziran 2011'de alınan karar doğrultusunda Suriye'ye ihracat ve ithalat kısıtlamaları, belirli işletmelerin finansmanına ilişkin kısıtlamalar ve altyapı projelerine kısıtlamalar getirilmiş, ticaret için mali desteğin kısıtlanması, fonların ve ekonomik kaynakların dondurulması kararlaştırılırken, finans ve taşımacılık sektörüne yönelik yaptırımlar devreye girmiştir. Alınan karar sonrası kısa zaman içerisinde Syritel ve El Vatan gazetesi gibi iletişim kurumlarına, Suriye Havayolları gibi ulaşım kurumlarına, Suriye ticaret bankası gibi finans kurumlarına, petrol şirketlerine ve içişleri ve savunma bakanlığı gibi kamu kuruluşlarına yaptırım uygulanmıştır (European Union, 1 Haziran 2013). Bireysel yaptırımlarda olduğu gibi şirket ve kurumlara karşı uygulanan ekonomik yaptırımlar, ilerleyen yıllarda devam etmiş ve yaptırım uygulanan kurum sayısı, Ocak 2019'da 76'ya ulaşmıştır (European Union, 21 Ocak 2019). AB'nin Suriye'ye karşı devreye soktuğu bir diğer önemli araç, ambargo olmuştur. 9 Mayıs 2011'de AB, Suriye topraklarının tamamında geçerli olmak üzere silah ambargosu 
uygulamaya başlarken (Taşdemir, 2016: 160), Lazkiye'deki şiddet olayları sonrasında Suriye'yle petrol ve petrol ürünleri alım-satımına yönelik ambargo kararı almış ve ilerleyen aylarda bu ambargonun kapsamını genişletmiştir (Van de Graaf, 2013: 146).

Suriye'ye yaptırım uygulama konusunda $A B D, A B$ 'ye benzer bir yol izlemiştir. ABD, kısa zaman içerisinde Suriye yönetimiyle ilişkili bireylere ve kurumlara karşı yaptırım uygulamaya başlamıştır. Nisan ayının sonunda Atıf Necip, Mahir Esad, Ali Memluk gibi Suriye yönetiminin önemli isimlerine yaptırım uygulama kararı alan $A B D$ (Executive Order 13572, 3 Mayıs 2011), Mayıs ayında bu listeyi daha da genişlemiş ve başta Suriye Cumhurbaşkanı Beşşar Esad ile Cumhurbaşkanı vekili Faruk El Şaara olmak üzere yedi yeni kişiye yaptırım uygulamaya başlamıştır (Executive Order 13573, 20 Mayıs 2011). ABD, ayrıca Ağustos ayında Suriye yönetimiyle petrol alımsatımı gibi çeşitli işlemleri de yasaklamıştır (Executive Order 13582, 22 Ağustos 2011). 2012'nin Nisan ve Mayıs aylarında ABD, yaptırımlarının kapsamını genişletirken, Syriatel ve Datak Telecom gibi Suriyeli şirketlere yaptırım uygulamaya başlamıştır (Executive Order 13582, 24 Nisan 2012). ABD, 2015, 2018 ve 2019 yıllarında Suriye'ye yönelik yaptırımlarını genişletmiş (U.S. Department of the Treasury, 2 Nisan 2019) ve hatta Suriye'ye petrol satışında bulunan Rusya ve İran'a da yaptırım uygulamaya başlamıştır (U.S. Department of the Treasury, 25 Mart 2019).

\subsection{BMGK'yı Devreye Sokma}

BMGK'nın daimi üyeleri ABD, Fransa ve İngiltere, BMGK'da Suriye yönetimine karşı alınacak sert önlemlerle krizi sonlandırılmaya çalışarak yeni bir aracl, hemen 2011 yılında devreye sokmuştur. Suriye'deki çatışmaların şiddetlenmesiyle bağlantılı olarak, bu üç daimi üye, BM ve uluslararası örgütleri harekete geçirmeye çalışırken, BMGK başta olmak üzere BM nezdinde Suriye yönetimine karşı çeşitli girişimlerde bulunmuştur. Fakat BM nezdindeki girişimler, Rusya ve Çin'in krize farklı yaklaşımları sebebiyle Suriye yönetimine karşı sözlü uyarıların ve kınamaların ötesine geçememiştir.

Mart 2011-Aralık 2019 arası Çin ve Rusya'nın veto ettiği 14 BMGK karar taslağının oluşmasında $A B D$, İngiltere ve Fransa ön plana çıkmıştır. Veto edilen 14 tasarının oluşturulmasında ABD 9, İngiltere 
10, ve Fransa 10 kez yer almıştır. ${ }^{*}$ Bu üç üyenin BMGK nezdinde Suriye krizine dair istedikleri kararları alamaması üzerine bu aktörler, 'Suriye Halkının Dostları Toplantıları' gibi uluslararası girişimlerde yer alarak hem uluslararası toplumu harekete geçirmeye çalışmış hem de krize yönelik benzer yaklaşım sergileyen bölgesel ve uluslararası aktörlerle iş birliklerini arttırmıştır. ABD, İngiltere ve Fransa, Suriye Halkının Dostları Toplantıları'yla birlikte ayrıca Suriyeli muhalif gruplara desteğini arttırarak hedeflerine ulaşmaya çalışmıştır.

\subsection{Muhalif Grupların Desteklenmesi}

$A B D$, İngiltere ve Fransa, ayrıca Suriye muhalefetine yardım sağlayarak hedeflerine ulaşmaya çalışmıştır. Suriye krizi çerçevesinde bu aktörler gerek siyasi gerekse askeri muhalefete çeşitli destek ve yardımlarda bulunmuş, fakat bu yardımlar, yeni tartışmaları da beraberinde getirmiştir. Suriye muhalefetine sağlanan destekler kabaca diplomatik ve maddi destekler olarak sınıflandırılabilir. Diplomatik destek açısından $A B D$, İngiltere ve Fransa, $A B$ ile birlikte muhalif grupların örgütlenmelerine yardımcı olmuş ve gerek Suriye Ulusal Konseyi'ni (SUK) gerekse Suriye Muhalif ve Devrimci Güçler Ulusal Koalisyonu'nu (SMDK) Suriye'nin temsilcisi olarak tanımıştır. ${ }^{+}$ SUK'la ilişkiler açısından Fransa, İngiltere (Foreign ve Commonwealth Office, 12 Ekim 2011) ve ABD Dışişleri Bakanları, Eylül-Ekim 2011'den itibaren SUK yetkilileriyle görüşmeye başlarken, muhalif gruplara sağlanan diplomatik destekte Kasım 2012 önemli bir tarih olmuştur. Kasım 2012'de SMDK'nın kurulmasının hemen ardından Fransa (Embassy Of France in Washington, D.C., $14 \mathrm{Kasım}$ 2012) ve İngiltere (Foreign ve Commonwealth Office, 20 Kasım 2012), Aralık ayında ise ABD (Sarı Ertem, 2018: 139) ve AB (European Commission, 19 Aralık 2012), SMDK'yı Suriye halkının meşru temsilcisi olarak tanımıştır. Bu tarihten sonra SMDK, bu üç büyük gücün Suriye krizi açısından en önemli partneri olmuştur.

\footnotetext{
* Bu uluslararası aktörlerin yanında Almanya ve Kuzey İrlanda 10'ar, İtalya ve İspanya 6'şar kez BMGK yasa tasarılarının oluşturulmasında yer alarak Suriye krizi açısından BM'de aktif olan diğer Avrupa ülkeleri olmuştur.

† 2012 yılında Suriyeli muhalif grupların çatı örgütü olarak kurulan koalisyon, zamanla 89 ülke tarafından Suriye'nin temsilcisi olarak tanınmış ve hatta 2013 yılında İstanbul'da geçici hükümet kurmuştur. İçerisinde SUK, Müslüman Kardeşler gibi siyasal oluşumların yanı sıra ÖSO ve Liva El Tevhid gibi askeri oluşumları da barındıran koalisyon, hedeflerini sivil ve askeri muhalefeti birleştirmek, geçiş hükümetini oluşturmak ve örgütü Suriye'nin tek meşru temsilcisi haline getirmek olarak tanımlamıştır. Koalisyonla ilgili ayrıntılı bilgi için bkz: The National Coalition for Syrian Revolution and Opposition Forces (t.y.) 19.08.2020 tarihinde https://en.etilaf.org/ adresinden ulaşılmıştır.
} 
$A B D$, İngiltere ve Fransa için muhalif gruplara sağlanan maddi yardımlar da önemli bir araç olurken ABD, bu üç devlet arasında Suriye muhalefetine en çok maddi yardım sağlayan BMGK üyesi olmuştur. 2013 yılının sonunda ABD, başta SMDK olmak üzere Suriye muhalefetine ve Özgür Suriye Ordusu'na (ÖSO) bağlı olan Yüksek Askeri Konsey'e 260 milyon dolarlık "öldürücü olmayan" yardımda bulunduğunu açıklarken, (U.S. Department of State, 12 Aralık 2013) bu oran, Ekim 2015'te 500 milyon dolara ulaşmıştır (U.S. Department of State, 31 Ekim 2015). İngiltere ise Mayıs 2013'e kadar Suriye muhalefetine 12 milyon dolarlık yardımda bulunurken, Mayıs 2013'te 10 milyon dolarlık yeni bir yardımda bulunmuştur (Foreign ve Commonwealth Office, 13 Mayıs 2013). İngiltere, ayrıca Kasım 2013'te ÖSO'ya 1 milyon dolarlık "öldürücü olmayan" yardımda bulunmuştur (Foreign ve Commonwealth Office, 1 Mayıs 2014). 2014 yılından itibaren özellikle ABD'nin temel kaygısı Daeş'le mücadeleye kaydığı için Suriye muhalefetine yapılan yardımlar, başta SDG ve YPG olmak üzere Daeş'le mücadele eden gruplara kaymış, muhalefete yapılan yardımların azalması ise Suriye muhalefetinin etkinliğini sınırlandırmıştır.

$A B$ açısından da Suriye muhalefetine sağlanan maddi yardımlar önemli olmuştur. Muhalif gruplara maddi destek için AB, 22 Nisan 2013 tarihinde muhaliflerin birçok petrol sahasını ele geçirmesinin etkisiyle Suriye'ye uyguladığı petrol ambargosunu yumuşatarak muhaliflerin ham petrol satışına izin vermiştir (Council of the European Union, 22 Nisan 2013). 2013 yılında AB, ayrıca 2011 yılında uygulamaya koyduğu silah ambargosunu muhalifler lehine önce yumuşatmış, sonra tamamen kaldırmıştır. Bu bağlamda Şubat 2013'te AB, ambargo kararını "öldürücü olmayan" askeri malzemelerin SMDK'ya gönderilmesine izin verecek şekilde değiştirmiş, 27 Mayıs'ta ise muhaliflere yönelik silah ambargosunu tamamen kaldırmıştır (Council of the European Union, 27 Mayıs 2013).

$A B D$, İngiltere ve Fransa, Suriye krizine farklı araçlarla müdahil olarak taleplerini kabul ettirmeye ve hedeflerine ulaşmaya çalışmıştır. $A B D$ ve $A B$, Mart 2011 sonrası diplomatik ve ekonomik yaptırımları devreye sokarak, önce Suriye yönetiminin siyasalarını değiştirmeyi hedeflemiş, sonrasındaysa Suriye'de yönetimi değiştirmeye çalışmıştır. $A B D$, Fransa ve İngiltere'nin hayata geçirdiği ikinci strateji, BMGK üzerinden krize çözüm arama olmuştur. İlk kez Ekim 2011'de BMGK'da oylanan Suriye krizi, ilerleyen yıllarda $A B D$ ve Avrupa ülkeleri 
tarafından sık sık BMGK'nın gündemine getirilmiş, fakat Çin ve Rusya tarafından tasarılar veto edilmiştir. Yaptırımların istenilen etkiyi sağlayamaması ve BMGK'da Suriye yönetimine karşı sert tedbirlerin alınamaması sonucunda ABD, İngiltere ve Fransa, Suriyeli muhalif gruplara diplomatik ve maddi desteklerini arttırarak hedeflerine ulaşmaya çalışmıştır. Fakat özellikle Daeş'in 2014 yılından itibaren Suriye içerisinde etkinliğini arttırmasıyla birlikte, bu aktörlerin temel ilgileri, Daeş'le mücadeleye, yardımları ise SDG ve YPG'ye kaymıştır.

\section{RUSYA VE ÇİN'İN HAYATA GEÇİRDİĞİ ÖNLEMLER}

Rusya ve Çin, Suriye krizi boyunca krize dışarıdan müdahale edilmesine karşı çıkarken, Suriye krizinin "uluslararası barış ve güvenliğe tehdit oluşturmadığını" savunarak, dışarıdan müdahalelerin sakıncalarına dikkat çekmiştir. Bu yüzden Suriye yönetiminin dışarıdan müdahalelerle değişmesini engellemeye çalışan Rusya ve Çin, krizin çözümünü taraflar arası siyasi görüşmeler olarak tanımlamıştır. 2011 sonrası Rusya ve Çin, kendi yaklaşımları doğrultusunda üç temel stratejiyi hayata geçirmiş ve bu stratejiler, $A B D$, Fransa ve İngiltere'nin önlemlerinin etkilerini sınırlandırmıştır. Bu iki büyük güç, 2011 sonrası Suriye yönetimine diplomatik, ekonomik ve askeri destek sağlayarak hedeflerini korumaya çalışmıştır. Çin'in desteği daha çok diplomatik ve ekonomik boyutta kalırken, Rusya'nın askeri desteği krizin dönüşümünde önemli olmuştur. Rusya, Eylül 2015 sonrası Suriye'deki çatışmaların aktif tarafı haline gelmiş ve Rusya'nın iç savaşa müdahalesi yereldeki dengelerin değişmesine sebep olmuştur. Diplomatik destekle ilişkili olarak bu iki aktör, BMGK'da Suriye yönetimine karşı sert tedbirlerin alınmasını engellemiştir. Ağırlıklı olarak Rusya'nın veto ettiği BMGK kararlarının birçoğunda Çin de veto yetkisini kullanmıştır. Üçüncü olarak krizin çözümü konusundaki yaklaşımlarına uygun olarak Rusya ve Çin, muhalif gruplarla ve Suriye yönetimiyle görüşmeler gerçekleştirerek krize siyasi bir çözüm bulmaya çalışmıştır.

\subsection{Suriye Yönetimine Destek Sağlama}

2011 sonrası Suriye içerisinde artan şiddet, Rusya ve Çin açısından da önemli bir sorun olmuştur. Bu bağlamda ABD, İngiltere ve Fransa gibi Rusya (President of Russia, 5 Ağustos 2011) ve Çin de (Embassy of the People's Republic of China in the Hellenic Republic, 10 Şubat 2012) Suriye içerisindeki krizin sonlanması için reformların önemine dikkat çekmiştir. Rusya ve Çin, reformların önemi konusunda diğer 
daimi üyelere benzer bir yaklaşım sergilese de ABD, İngiltere ve Fransa'nın Suriye krizine yaklaşımını taraflı olarak görmüş ve bu 'üç daimi üyenin' Suriye krizini sonlandırmaktan çok, kendi çıkarlarını gerçekleştirmek için Suriye'ye müdahil olduklarını savunmuştur. Bu bağlamda Rusya ve Çin, krize kendi yaklaşımlarına uygun bir çözüm aramaya çalışırken, diplomatik düzlemde Suriye yönetimine karşı atılacak adımlara karşı çıkmıştır.

Rusya'nın diplomatik desteğin ötesinde ekonomik ve askeri desteği, krizin ilk yıllarında belirgin olmuştur. Örneğin, başta ABD ve $A B$ olmak üzere çok sayıda bölgesel ve uluslararası aktörün Suriye yönetimine yaptırım uyguladığı bir dönemde Rusya, 2012-2013 yılı için Suriye'yle 4 milyon dolarlık silah anlaşması imzalarken, Mayıs 2013'te Suriye'ye anti gemi seyir füzeleri göndererek askeri desteğini arttırmıştır (Gordon ve Schmitt, 2013). 2015 yılından itibaren Rusya'nın desteği daha doğrudan ve görünür olmuştur. Haziran 2015'te Suriye'yle yapılan görüşmeler sonucu Rusya, Daeş ve ülke içerisindeki aşırılık yanlılarına karşı mücadelelerinde Suriye yönetimine destek vereceğini belirtirken (The Ministry of Foreign Affairs of the Russian Federation, 29 Haziran 2015), Eylül ayında Suriye'ye insani yardımların yanı sıra askeri yardımda da bulunduğunu açıklamıştır (The Ministry of Foreign Affairs of the Russian Federation, 10 Eylül 2015). 30 Eylül tarihinde 'davetle müdahale' çerçevesinde Rusya'nın Suriye'de operasyonlara başlamasıysa hem Suriye krizi için hem de ülke içerisindeki çatışmalar için önemli bir gelişme olmuştur. İlerleyen yıllarda Rusya'nın askeri desteği devam ederken, Ekim 2016'da Rusya, Tartus'ta bulunan deniz üssüne S-300 füzeleri yerleştirmiştir (Radio Free Europe, 4 Ekim 2016), 2017'de iki ülke, Rusya'nın Suriye'deki iki askeri üssünde varlığını süresiz olarak sürdürmesini ve Tartus'taki tesislerini genişletmesini sağlayan bir anlaşma imzalamıştır (Radio Free Europe, 29 Aralık 2017). Çin ise doğrudan yardım konusunda Rusya kadar aktif olmasa da Suriye yönetimiyle 2015 ve 2017 yıllarında imzaladığı 6.18 milyon (The State Council: The People's Republic Of China, 25 Aralık 2015) ve 16 milyon dolarlık (The State Council: The People's Republic Of China, 6 Şubat 2017) insani yardım anlaşmalarıyla ve Suriye'nin yeniden inşasında yer alma isteğini duyurmasıyla (The State Council: The People's Republic Of China, 28 Eylül 2018) Suriye yönetimine önemli ölçülerde ekonomik destek sağlamıştır. 


\subsection{BM ve BMGK'nın Devreye Sokulmasını Engelleme}

Çin ve Rusya'nın Suriye krizi adına en önemli hedeflerinden biri, BMGK'da Suriye yönetimine karşı "dengesiz" bir kararın çıkmasının engellenmesi ve olası bir askeri müdahalenin önüne geçilmesi olmuştur. Kriz boyunca Çin, Suriye dışındaki aktörlerin Suriye'nin içişlerine müdahale etmemesini talep ederken, bu yaklaşımını, iç siyasete karışmanın yanlış ve sakıncalı olduğu argümanı üzerinden üretmiştir (Miş ve Özdemir, 2015: 187). Rusya da Çin'e benzer bir tutum sergileyerek, Suriye krizine dışarıdan yapılacak bir müdahalenin istikrarsızlaştırıcı etkilerine vurgu yapmış ve $A B D$, Fransa ve İngiltere'nin krize yaklaşımlarının tek taraflı olduğunu savunmuştur. Suriye krizinin başlangıcından itibaren pozisyonlarını koruyan Rusya ve Çin, Mart 2011 sonrası BMGK'da veto yetkilerini kullanarak, kendi yaklaşımlarının dışında herhangi bir kararın çıkmasını engellemiştir. Aralık 2019'a kadar BMGK'da Rusya, Suriye kriziyle ilgili 14 tasarıda veto yetkisini kullanırken, Çin ise 14 tasarının 8'sinde Rusya'nın yanında veto yetkisini kullanmıştır.

Ekim 2011'de Rusya ve Çin, Suriye yönetiminin şiddeti sonlandırması ve bu doğrultuda gerekli önlemlerin alınması yönündeki BMGK karar teklifini reddederek, Suriye krizinde ilk kez veto yetkilerini kullanmıştır. Tasarı, Suriye yönetimi tarafından sivillere karşı güç kullanımını, sebep olunan ölümleri ve sistematik insan hakları ihlallerini kınamış, tüm devletlere, Suriye'ye silahların ve her türden ilgili materyalin doğrudan ya da dolaylı olarak temin edilmesinin, satılmasının ya da devredilmesinin sınırlandırılması çağrısında bulunmuştur. Suriye'nin bu tasarıyı 30 gün içinde uygulaması istenirken, aksi takdirde BM Şartı'nın 41. maddesi kapsamında ekonomik ve diplomatik ilişkilerin askıya alınması gibi önemlerin hayata geçirilmesi önerilmiştir (United Nations Security Council, 4 Ekim 2011). Çin, BMGK'nın Suriye'nin egemenliğine ve toprak bütünlüğüne saygı göstermesine ve içişlerine karışmaması gerektiğine vurgu yaparken, Rusya, tasarının Suriye yönetimini suçlayan bir dile sahip olduğunu ve askeri müdahalenin kabul edilemezliğini gerekçe göstererek, BMGK tasarısını reddetmiştir (United Nations Security Council, 4 Ekim 2011).

2012 yılında Çin ve Rusya, BMGK'da benzer tutumlarını devam ettirmiştir. Ocak 2012'de BMGK'da sunulan barış planı çerçevesinde Beşşar Esad'ın görevini yardımcısına devretmesi, geçici bir ulusal birlik hükümetinin kurulması ve ulusal diyalog ortamı sağlanarak erken 
seçimlerin yapılması talep edilmiş ama Rusya ve Çin, Cumhurbaşkanı Esad'ın istifasının önkoşul olarak talep edilmesine karşı çıkmıştır (Allison, 2013: 799). Temmuz 2012'de Rusya ve Çin, BMGK'da üçüncü kez veto yetkisini kullanarak Annan Planı'na* uyulmaması durumda Suriye'ye karşı yaptırım öngören tasarıyı veto etmiştir. 19 Temmuz 2012'de Fransa, Almanya, İngiltere ve ABD tarafından önerilen ve şehir merkezlerine ve nüfusun yoğun olduğu bölgelere karşı askeri harekatların sona erdirilmesini ve her türlü ağır silahların kullanımının durdurulmasını Suriye yönetiminden talep eden tasarı, Suriye yönetiminin bu taleplere 10 gün içerisinde uymaması durumunda ekonomik, diplomatik, ulaşım ve haberleşme ilişkilerinin kesilmesi dahil çeşitli önlemlerin devreye girmesini öngörmüştür (United Nations Security Council, 19 Temmuz 2012). Çin, tasarının yalnızca tek bir tarafa baskı uygulayan dengesiz bir içeriğe ve siyasi çözümden ziyade bölgesel barış ve istikrara zarar verici bir niteliğe sahip olduğu gerekçeleriyle tasarıyı veto ederken Rusya, çözüm için çatışan taraflar arasında siyasi diyaloğa vurgu yapıp, tasarıyı öneren ülkelerin kendi "jeopolitik tasarımları" doğrultusunda öneride bulunduklarını belirtmiştir (United Nations Security Council, 19 Temmuz 2012).

İlerleyen yıllarda Çin ve Rusya, BMGK'daki pozisyonlarını korumuştur. Mayıs 2014'te Fransa, BMGK'ya Suriye'deki çatışmalarda insanlığa karşı suç ve savaş suçu işleyenlerin Uluslararası Ceza Mahkemesi'nde (UCM) yargılanmasını öngören bir taslak iletse de bu taslak, Çin ve Rusya tarafından veto edilmiştir. Çin, UCM'yi etkinleştirmek isteyen herhangi bir eylemin devletlerin yargısal egemenliğine ve tamamlayıcılık ilkesine dayanması gerektiğini belirtirken, Suriye krizinin çözümünün sadece siyasi diyalog yoluyla gerçekleşebileceğini savunarak tasarıyı veto etmiştir (Ministry of Foreign Affairs of the People's Rebuplic of China, 23 Mayıs 2014). Rusya ise önceki tasarılarda olduğu gibi bu tasarının da tek taraflı olduğu ve siyasi çözüme yardımcı olmayacağı gerekçeleriyle veto hakkını kullanmıştır (United Nations Security Council, 22 Mayıs 2014). 8 Ekim 2016 tarihli tasarı ise Rusya tarafından yine tek taraflı olduğu, Suriye içerisindeki krizin tek sorumlusu olarak Suriye yönetiminin

\footnotetext{
* Annan Planı'na göre ülke içerisinde şiddetin sona ermesi ve ateşkesin sağlanması, insani yardımların sağlanması, gazetecilerin ülke içerisinde serbest dolaşımı, keyfi tutuklamalar ve gözaltıların sona ermesi ve barış̧ıl protesto hakkına saygı duyulması konusunda Suriye krizinin tarafları anlaşmaya varmışıı. Ayrıca BMGK, plan çerçevesinde Suriye'ye gözlemci heyeti göndermiştir. Fakat 12 Nisan 2012'de Annan Planı çerçevesinde yürürlüğe giren ateşkes, Mayıs 2012'de Hama'da yapılan operasyonlar sırasında yüzden fazla kişinin ölmesi sonucunda sona ermiştir.
} 
gösterildiği ve silahlı gruplara herhangi bir tedbir getirilmediği gerekçeleriyle veto edilmiştir (The Ministry of Foreign Affairs of the Russian Federation, 8 Ekim 2016). 2017 yılından itibaren Suriye'de yerel çatışmaların yanı sıra kimyasal silah kullanımı, tekrar ön plana çıkan konu olmuş ve Suriye'deki kimyasal silahların kullanımıyla ilgili beş tasarıdan dördü, sadece Rusya tarafından veto edilirken, 28 Şubat 2017 tarihli tasarı, Rusya'nın yanında Çin tarafından da veto edilmiştir. Rusya, genel olarak tasarıların tek taraflı olduğu tezi üzerinden veto yetkisini kullanmaya devam ederken, kimyasal silah kullanımı açısından BMGK kararı olmadan Suriye'ye düzenlenen hava saldırılarına da tepki göstermiştir (Permanent Mission of the Russian Federation to the United Nations, 12 Nisan 2017).

\subsection{Muhalif Gruplarla Görüşme ve Krizin Taraflarını Bir Araya Getirme}

Rusya ve Çin, Suriye krizinin çözümü olarak Suriye yönetimi ile Suriye muhalefeti arasında diyaloğu savunmuştur (Ministry of Foreign Affairs of the People's Republic of China, 31 Aralık 2016). Bu hedef için bu iki aktör, tarafları bir araya getirmeye çalışmış ve krize siyasi çözüm sağlamayı hedefleyen girişimleri desteklemiştir. Bu yaklaşım doğrultusunda, Ağustos 2012'de dönemin Çin Dışişleri Bakanlığı Sözcüsü Qin Gang, Suriye Cumhurbaşkanı Beşşar Esad'ın danışmanı Buseyna Şaban'ın Çin ziyareti öncesi yaptığı açıklamada, Çin'in Suriye yönetimi ve muhalefet arasında dengeli bir şekilde çaba harcadığını ve tüm taraflarla iletişim halinde olduklarını belirterek (Ministry of Foreign Affairs of the People's Republic of China, 11 Nisan 2012), yakın gelecekte Suriye'deki ilgili muhalif grupları, Çin'e davet etmeyi düşündüklerini ifade etmiştir (Ministry of Foreign Affairs of the People's Republic of China, 13 Ağustos 2012). Bu bağlamda Çin, Ağustos 2012'de Suriye yönetimiyle, Eylül ayında ise "Demokratik Değişim için Ulusal Koordinasyon Komitesi" (UKK)* ile görüşerek, krize siyasal

\footnotetext{
* SUK ve SMDK çizgisinden uzak olan UKK, 13 farklı siyasi grubun bir araya gelmesiyle kurulmuştur. Komite krizin sonlanması için siyasi mahkumların serbest bırakılmasını, ordunun şehirlerden çekilmesini, Baas Partisi'nin tekelinin sona ermesini, olağanüstü halin kaldırılmasını, yabancı gazetecilerin Suriye'ye girişlerine izin verilmesini ve şiddetin sorumlularının kovuşturulmasını talep ederken krizin çözümü için geçici bir hükümetin kurulmasını, kilit reformların başlatılmasını, yeni bir anayasanın hazırlanmasını ve siyasi partilerin kurulmasını istemiştir. UKK, dış müdahaleye, devrimin dini ve mezhebi bir çizgiye kaymasına ve askerileşmesine karşı bir tutum sergilemiştir. Bu bağlamda Suriye'nin Dostları gibi oluşumlardan uzak duran oluşum, SUK ve SMDK'yı dış bağlantılı oldukları gerekçesiyle eleştirirken SUK ve SMDK ise UKK'yı Suriye "rejiminin" uzantısı olarak tanımlamışır. Komiteyle ilgili ayrıntılı bilgi için bkz: Carnegie Middle East Center (2012). National Coordination Body for Democratic Change. 15.01.2012. 17.08.2020 tarihinde http://carnegie-mec.org/publications/?fa=48369 adresinden ulaşılmıştır.
} 
çözüm üretmeye çalışmıştır (Reuters, 17 Eylül 2012). Çin'in farklı muhalif gruplarla görüşmeleri, ilerleyen yıllarda da devam etmiştir.

Rusya da Suriye iç savaşının baş aktörleri olan Suriye muhalefeti ve Suriye yönetimiyle görüşmeler düzenleyerek krize siyasi bir çözüm üretmeye çalışmıştır. Rusya'nın taraflarla görüşüp krize çözüm bulmak için gerçekleştirdiği ilk girişimlerden biri, 2012 yılında meydana gelmiştir. 2012 yılında Rusya-Suriye görüşmeleri sonunda yapılan açıklamada, Rusya ile Suriye'nin Beşşar Esad'ın yetkilerinin azaltılarak yeni bir anayasa için referanduma gidilmesi, ülke içerisinde genel seçimlerin yapılması ve Suriye yönetiminin muhaliflerle görüşmesi konularında uzlaşıya vardıkları belirtilmiştir (Miş, 2014: 226). Rusya, 2014 yılından itibaren taraflarla görüşmelerini sıklaştırarak, Suriye yönetimi ile Suriyeli muhalifleri aynı masaya oturtmaya çalışmıştır. Kasım 2014'te Rusya Devlet Başkanı Putin, dönemin Suriye Dışişleri Bakanı Velid Muallim ile görüşmüş ve görüşme sonrasında Suriye'deki krizin sona ermesi için muhalifler ile Suriye yönetimini buluşturacak "Moskova Platformunun" kurulmasını önermiştir (Al Jazeera Türk, 26 Kasım 2014). Ayrıca Kasım 2014'te Rusya, SDMK lideriyle Rusya'da görüşmüş ve taraflar, Suriye içindeki çatışmaları sonlandırmaya yönelik siyasi müzakere için Suriye yönetimiyle görüşülmesi konusunda anlaşmaya varmıştır (Miş ve Özdemir, 2015: 186). Rusya'nın girişimleri sonucunda Suriye yönetimini ve muhalefeti, Ocak 2015'te Rusya'da bir araya gelebilmiştir (The Ministry of Foreign Affairs of the Russian Federation, 28 Ocak 2015).

Suriye içindeki çatışmalara ve krize, siyasi çözüm üretmeye çalışan Rusya, Astana Süreci'yle birlikte bu çabalarını uluslararası platformlara taşımış ve krize farklı yaklaşım sergileyen yerel, ulusal, bölgesel ve uluslararası aktörleri, bir araya getirerek krize farklı düzlemlerde çözüm aramıştır. 20 Aralık 2016'da İran, Türkiye ve Rusya'nın dışişleri bakanları, Kazakistan'ın Astana kentinde barış görüşmelerinin yapılması için "BMGK'nın 2254 kararı" uyarınca anlaşmış ve taraflar, Suriye'de ülke çapında ateşkes planının yürürlüğe konulmasına karar vermiştir (Hubbard ve Sanger, 20 Aralık 2016). Rusya, ateşkesin şiddeti sona erdirecek mekanizmaları içerdiğini ve siyasi müzakerelerin başlamasına yardımcı olacağını açıklarken, bu girişim, "31 Aralık 2016'da kabul edilen 2336 sayılı karar" ile BMGK tarafından onaylanmıştır (United Nations Security Council, 31 Aralık 2016). Ayrıca 2017'den itibaren Suriye içerisinde "çatışmasızlık bölgelerinin" kurulması kararlaştırılarak, taraflar arasındaki gerilim 
düşürülmeye çalışılmıştır. Çeşitli muhalif gruplar ve Suriye yönetimi tarafından kabul edilen çatışmasızlık bölgeleri ayrıca İran, Rusya ve Türkiye ve hatta ABD ve Ürdün (Francis, 9 Temmuz 2017) tarafından kabul görmüş ve krizin farklı düzlemlerindeki aktörleri tarafından desteklenmiştir. Bölgesel ve uluslararası aktörlerin dışında küresel örgütten de destek gören Astana Süreci, Rusya ve Çin'in krizin çözümü konusundaki yaklaşımını bölgesel ve uluslararası düzlemlerde daha fazla ön plana çıkarmıştır.

\section{BMGK'DA SURİYE KRİZIYYLE İLGİLİ ALINAN KARARLAR}

BMGK daimi üyelerinin krizin kaynağı ve çözümüne farklı yaklaşım sergilemeleri, krizin çözümünü zorlaştırsa da bu aktörlerin asgari memnuniyetinin sağlanabildiği durumlarda Suriye krizi ve ilintili konuların yönetimi, daha kolay olmuş ve hatta Cenevre ve Astana süreçleri gibi önemli referans noktaları ortaya çıkmıştır. BMGK'nın 2011 sonrası Suriye kriziyle ilgili aldığı kararlarda; Suriye içi çatışmalar ve ülke içi krizin sonlandırıması, Suriye'de kimyasal silah kullanımı ve kimyasal silahların yayılmasının önlenmesi, Suriye ile İsrail arasındaki ateşkesin devamı, bu iki ülke arasında bulunan Birleşmiş Milletler Gözlem Gücü'nün (UNDOF) güvenliğinin sağlanması ve ayrılma bölgesinde ortaya çıkan şiddetin önlenmesi, Suriye ve Irak'ta artan Daeş ve El Nusra Cephesi'nin faaliyetlerinin engellenmesi ve bölgenin barış ve güvenliğinin sağlanması konuları öne çıkmıştır.

2011 sonrası BMGK'da alınan bazı kararlar, Suriye krizi ve ilintili konular açısından önemli referans noktaları olmuştur. 2013 yılında alınan 2118 sayılı karar (United Nations Security Council, 27 Eylül 2013), kimyasal silah kullanımıyla ilgili ortaya çıkan krizin yumuşamasına yardımcı olurken, ${ }^{*} 2014$ yılındaki 2170 sayılı kararla (United Nations Security Council, 15 Ağustos 2014) Daeş ve El Nusra Cephesi terörist örgüt ilan edilmiştir. Bu kararla Daeş ve El Nusra'ya karşı finansal yaptırımlar gibi çeşitli tedbirleri devreye sokarak, Daeş'le mücadelede uluslararası iş birliğini arttıran küresel örgüt, 2115 sayılı kararla (United Nations Security Council, 14 Temmuz 2014) Suriye yönetiminin izni aranmaksızın insani yardımların Suriye'ye gönderilmesini kararlaştırmış ve bu kararla, ülke içindeki insani

* Bu kararla Suriye yönetimi elindeki kimyasal silahların teslim ve imhasını kabul ederken kimyasal silah kullanımıyla ilgili iddialar, 2017 ve 2018 yıllarında yeni gerilimlere sebep olmuştur. Suriye yönetiminin ülke içi çatışmalarda kimyasal silah kullandığına dair iddialar sonucunda 2017 yııında ABD, 2018 yııında ise $A B D$ ile birlikte İngiltere ve Fransa, Suriye'deki hedeflere hava saldırıları düzenlemiş ve bu saldırılar, Rusya'nın tepkisine yol açmıştır. 
krizlerin yumuşamasına yardımcı olmuştur. Suriye kriziyle ilintili bu konuların dışında BMGK'nın aldığı önemli kararlar, Cenevre Mutabakatı ve Astana Süreci'nin desteklenmesi konularında olmuştur. Temmuz 2012'de büyük güçlerin anlaştığı ve "Cenevre Mutabakatı'" olarak bilinen süreçle Annan Planı'nın desteklenmesi kabul edilirken, Suriye'deki anayasal düzen ve adalet sisteminin gözden geçirilmesi ile özgür ve çok partili seçimler için hazırlanılması kararlaştırılmıştır (United Nations General Assembly, 30 Temmuz 2012). Mutabakat sonucunda Suriye yönetimini ve muhalefetin üyelerini kapsayabilecek tam yönetim yetkisine sahip geçici hükümet organına ihtiyaç duyduğu ilan edilmiş ve Rusya ve Çin'in yaklaşımına da uygun olarak Beşşar Esad'ın istifası önkoşul olarak sunulmamıştır. Bu mutabakat, BMGK için önemli bir referans noktası olurken, BMGK aldığı kararlarda Cenevre I ve Cenevre II Konferansları'nda önerilen siyasi çözüm yollarının bir an önce yerine getirilmesini talep etmiştir (United Nations Security Council, 22 Şubat 2014). Benzer bir durum Astana Süreci'nde de ortaya çıkmış ve 31 Aralık 2016'da BMGK, aldığı kararla İran, Türkiye ve Rusya arasında Suriye krizinin çözümü için yürütülen süreci memnuniyetle karşıladıklarını ve Astana Süreci'ni desteklediğini belirterek (United Nations Security Council, 31 Aralık 2016) önkoşulsuz siyasi çözüm girişimlerine verdikleri desteği yinelemiştir.

BMGK'nın Rusya ve Çin'in yaklaşımına uygun olarak önkoşulsuz siyasi çözümü desteklemesi, bu iki büyük gücün krizin çözümünde ağırlık kazanmasına yardımcı olmuştur. Krize siyasi bir çözüm bulma adına ABD, İngiltere ve Fransa'dan farklı olarak, Rusya ve Çin, kapsayıcı bir yaklaşım sergilemiş ve Suriye yönetiminin yanında muhalif gruplarla da görüşmeler düzenlemiştir. Benzer bir şekilde Rusya, krize farklı yaklaşım sergileyen İran ve Türkiye'yle iş birliği geliştirerek farklı aktörlerin desteğini de sağlamıştır. Farklı düzlemdeki aktörlerin sürece dahil olmalarıysa Rusya ve Çin'in yaklaşımını süreç içerisinde öne çıkarmıştır. Siyasi çözüm girişimlerinin yanında sürece en aktif olarak müdahil olan Rusya ve ABD'nin dönüşen siyasaları da krizin dönüşümüne etki etmiştir. Suriye muhalefetine en çok maddi yardımda bulunan ABD'nin, yardımlarını 2014'ten itibaren Daeş'le mücadele eden gruplara kaydırmaya başlaması ve 2015 yılında Rusya'nın doğrudan iç savaşa taraf olması, iç savaştaki dengelerin bozulmasına sebep olmuştur.

Çin ve Rusya'nın önlemlerinin kriz açısından ağırlık kazanması ve iç savaştaki dengelerin değişmesi, krizin sınırlandırılmasında rol 
oynarken, BMGK'nın siyasal çözümü desteklemesi, son yıllarda ABD, Fransa ve İngiltere için de siyasal çözüm yollarını ön plana çıkarmıştır. Beşşar Esad yönetiminin iktidardan ayrılmasını önkoşul olarak sunmaktan vazgeçen bu daimi üyeler için Rusya, Suriye ve Çin'le gerilimler devam etse de BMGK'nın 2254 sayılı kararı, son yıllarda önemli bir referans olmuştur. Bu bağlamda örneğin 2019 yılında ABD Dışişleri Bakanı, krize askeri bir çözüm sağlanamayacağını kabul ederken, BMGK'nın 2254 sayılı kararına vurgu yaparak, siyasal çözüm yollarını desteklediğini açıklamıştır (U.S. Department of State, 10 Aralık 2019). Benzer bir durum İngiltere ve Fransa için de meydana gelmiş ve her iki aktör, krizin siyasal yollarla çözülmesini savunmuş ve ülke içerisinde artan çatışmaların siyasi çözüm girişimlerine zarar verdiğini belirtmiştir (Embassy of France in Washington, D.C., 27 Aralık 2019). Fakat BMGK'nın 5 daimi üyesinin siyasal çözüme vurgu yapmaları, bu aktörleri sürecin işletilmesi konusunda aynı noktaya getirmemiş ve siyasal çözümsüzlük konusunda daimi üyeler, birbirlerini suçlamaya devam etmiştir. Bu bağlamda örneğin ABD, Aralık 2019'da insani yardımların Suriye'ye gönderilmesi konusunda Çin ve Rusya'nın BMGK'da kullandıkları vetoyu eleştirirken (U.S. Department of State, 21 Aralık 2019) Fransa, Rusya'yla Suriye konusu da olmak üzere önemli konularda görüş ayrılıkları yaşadıklarını ve taraflar arasında güvensizlik olduğunu duyurmuştur (Embassy of France in Washington, D.C., 15 Ekim 2019). İngiltere ise İdlib'de düzenlenen askeri operasyonlara tepki gösterip, bu tip operasyonların siyasi çözümü engellediğini belirtmiştir (Foreign ve Commonwealth Office, 7 Mayıs 2019). Diğer taraftan önceki yıllarda olduğu gibi Rusya, Batılı güçlerin kendi siyasi çıkarları doğrultusunda hareket etmeye devam ettiğini belirtirken (The Ministry of Foreign Affairs of the Russian Federation, 23 Aralık 2019), Çin, Batılı aktörlerin iki yüzlü davrandıklarını ve insani konuları kendi çıkarları doğrultusunda kullandıklarını dile getirerek tepki göstermiştir (Ministry of Foreign Affairs of the People's Rebuplic of China, 23 Aralık 2019).

\section{SONUÇ}

Mart 2011'de Arap Baharı çerçevesinde Suriye'de başlayan gösteriler, kısa bir zaman içerisinde karşılıklı çatışmaya ve iç savaşa dönüşmüştür. Suriye içerisindeki çatışmalar, uluslararası gündemin önemli bir konusu haline gelmiş ve BMGK'nın daimi üyeleri, kendi yaklaşımları ve Suriye yönetimiyle önceki yıllardan gelen ilişkileri doğrultusunda krize müdahil olmuştur. Önceki yıllarda Suriye 
yönetimiyle iyi ilişkilere sahip olmayan $A B D$, Fransa ve İngiltere, krizin kaynağını Suriye yönetiminin ülke içerisinde uyguladığı yoğun şiddet olarak görürken, Rusya ve Çin, Suriye içindeki çatışmaların uluslararası barış ve güvenliğe tehdit oluşturmadığını savunmuş ve dışarıdan yapılacak müdahalelerin krizin kötüleşmesine sebep olacağını belirtmiştir. Bu iki aktör, ayrıca krizin kaynağı konusunda Suriye içinde şiddet uygulayan diğer aktörlere de dikkat çekmiştir. Suriye krizinin kaynağını Suriye yönetiminin siyasaları olarak gören ABD, İngiltere ve Fransa, krizin çözümünü Suriye yönetiminin değişmesi olarak belirlerken, Suriye yönetimiyle iyi ilişkilere sahip ve Libya'ya düzenlenen NATO operasyonlarına tepkili olan Çin ve Rusya, krizin çözümü için taraflar arasında siyasal görüşmelere vurgu yapmıştır.

BMGK'nın daimi üyelerinin kendi yaklaşımları doğrultusunda devreye soktuğu önlemlerse kendi içerisinde bir çeşit denge yaratmıştır. $A B D$, İngiltere ve Fransa öncelikli olarak diplomatik ve ekonomik yaptırımlarla hedeflerine ulaşmaya çalışırken, Rusya ve Çin, Suriye yönetimine diplomatik, ekonomik ve askeri destek sağlamıştır. Bu bağlamda ABD, Suriye'deki şiddet olaylarıyla ilgili çok sayıda kişi ve kuruma yaptırım uygulamış, İngiltere ve Fransa'nın da etkisiyle $A B$ ise Ocak 2019'a kadar 274 kişi ve 76 kuruma yönelik yaptırımları devreye sokmuştur. Diğer taraftan Rusya ve Çin, krizin ilk yılından itibaren Suriye yönetimine diplomatik destek sağlarken, ilerleyen yıllarda bu iki aktör, Suriye yönetimine insani veya maddi yardımda bulunmuştur. Rusya'nın 2015 yılında Suriye'deki çatışmalarda yer almaya başlamasıyla birlikte Suriye yönetimine sağlanan destek, yeni bir boyut kazanmış ve bu boyut, yereldeki çatışmaların seyrini değiştirmiştir.

$A B D$, İngiltere ve Fransa, ikinci olarak BMGK'yı devreye sokmaya çalışmış, fakat Çin ve Rusya, Suriye yönetimine karşı sert tedbirlerin alınmasını engellemiştir. Mart 2011-Aralık 2019 arası 14 BMGK tasarısı Rusya ve/veya Çin tarafından yanlı olduğu, askeri müdahalenin yolunu açacağı, başka jeopolitik çıkarları hedeflediği ve krize çözüm üretmediği gerekçeleriyle veto edilmiştir. Veto edilen 14 tasarının oluşturulmasında ABD 9, İngiltere 10, ve Fransa 10 kez yer alırken Rusya, bu tasarıların hepsini veto etmiş, Çin ise 8 tasarıda Rusya'yla birlikte veto yetkisini kullanmıştır.

Yaptırımların istenilen etkiyi sağlayamaması ve BMGK'da sert bir önlemin alınamamasının etkisiyle $A B D$, İngiltere ve Fransa, muhalif gruplara diplomatik ve maddi destek sağlayarak, Suriye'de siyasal 
değişimi hedeflemiştir. Diplomatik destek açısından bu aktörler, Kasım ve Aralık 2012'de SMDK'yı Suriye halkının resmi temsilcisi olarak tanırken, Suriye Halkının Dostları Toplantıları gibi girişimlere aktif destek vermiştir. Maddi destek açısından Ekim 2015'e kadar başta ÖSO olmak üzere Suriyeli muhalif gruplara ABD, 500 milyon dolar civarında, İngiltere ise 20 milyon dolardan fazla yardımda bulunmuştur. $A B$ ise zaman içerisinde Suriye'ye uyguladığı petrol ve silah ambargolarını muhalifler lehine yumuşatmıştır. Fakat $A B D$, İngiltere ve Fransa'nın Suriye muhalefetine sağladığı maddi ve askeri yardımlar, Rusya'nın Suriye yönetimine sağladığı yardımlar sonucu istenilen yönetim değişikliğini sağlayamamıştır. Rusya'nın Suriye'deki çatışmalarda yer almasının ötesinde Suriye'yle imzaladığı silah anlaşması ve Tartus'taki askeri üssün genişletilip kalıcı hale getirilmesi gibi askeri adımlar, Suriye muhalefetine yapılan yardımları etkisizleştirmiştir.

Uluslararası krizlerin çözümü açısından önemli olan BMGK'nın etkisi ise daimi üyelerinin uyuşmayan hedefleri yüzünden sınırlı olmuştur. Tarihteki diğer örneklere benzer şekilde şiddetin yoğun, krizin tarafları arasındaki gerilimin yüksek, krize taraf olan aktör sayısının fazla, büyük güçlerin aktif bir şekilde müdahil olduğu ve uzun bir döneme yayılan, Suriye krizine BM ve BMGK, aktif bir şekilde müdahil olmuştur. Bir başka ifadeyle, çok boyutlu olan ve birçok sorunu içerisinde barındıran Suriye krizi, küresel örgütün 2011 sonrası en önemli konularının başında gelmiştir. Fakat daimi üyelerin uyuşmayan talepleri yüzünden Mart 2011-Temmuz 2020 arası BMGK'da alınan 41 kararın birçoğu, sözlü uyarı ve kınamaların ötesine geçemezken, Suriye krizinin taraflarına yönelik sert önlemler veya ciddi teşvikler geliştirememiştir. Bir başka ifadeyle, daimi üyelerin uyuşmayan talepleri yüzünden, küresel örgütün en önemli organı Güvenlik Konseyi, Suriye krizinin yarattığı diğer önemli sorunların yönetimini kolaylaştırsa dahi krizin merkezinde yer alan krizin nasıl sonlanacağı ve Suriye'nin geleceğinin ne olacağı sorularına cevap üretememiştir. Bu etkisizliğin en temel sebebi ise daimi üyelerinin uyuşmayan hedefleridir.

Buna rağmen yine de Daeş'le mücadele, kimyasal silahların kullanılmasının engellenmesi ve insani yardımların Suriye'ye gönderilmesi için alınan kararlar, Suriye kriziyle ilintili sorunların yönetimini bir süreliğine de olsa kolaylaştırmıştır. Suriye krizinde güç kullanımından sakınan BMGK; Rusya ve Çin'in yaklaşımına uygun olarak siyasal çözüm girişimlerine destek vermiş ve bu bağlamda Cenevre ve Astana gibi uluslararası girişimleri doğrudan desteklemiştir. 
BMGK'nın önkoşulsuz siyasal çözüm girişimlerini desteklemesi, Rusya ve Çin'in Suriye krizindeki yaklaşımlarına meşruiyet sağlarken, ABD'nin Suriye krizindeki önceliklerinin değişmesi, İngiltere ve Fransa'nın ABD'yi takip etmesi ve Rusya'nın yereldeki çatışmalarda yer almaya başlamasıyla iç savaşta taraflar arasındaki denge bozulmuştur. Bütün bunların etkisiyle siyasal çözüm girişimleri; $A B D$, Fransa ve İngiltere tarafından da desteklenmeye başlanmış, fakat BMGK'nın daimi üyeleri, siyasal çözümün gerçekleşmemesi konusunda birbirlerini suçlamaya devam etmiştir.

\section{KAYNAKÇA}

Al Jazeera Türk. (2014). Rusya: Esed'i Desteklemeye Devam Edeceğiz. 26.10.2014. Erişim Adresi: http://www.aljazeera.com.tr/haber/rusyaesedi-desteklemeye-devam-edecegiz. Erişim Tarihi: 21.08.2020.

Allison, R. (2013). Russia and Syria: Explaining Alignment with A Regime in Crisis. International Affairs 89(4), 795-823.

Baldwin, D. A. (1971). The Power of Positive Sanctions. World Politics 24(1), 19-38.

Brecher, M. (2008). International Political Earthquakes. USA: The University of Michigan Press.

Brecher, M. \& Wilkenfeld, J. (1997). A Study of Crisis. USA: The University of Michigan Press.

Carnegie Middle East Center (2012). National Coordination Body for Democratic Change. Erişim Adresi: http://carnegiemec. org/publications/?fa=48369. Erişim Tarihi: 10.12.2020.

Council of the European Union. (2013). Council Declaration on Syria: 3241st Foreign Affairs Council meeting Brussels. 27.05.2013.

DeRouen Jr, K. (2003). The Role of the UN in International crisis Termination, 1945-1994. Defence and Peace Economics 14(4), 251260.

Embassy of France in Washington, D.C. (2012). Syria. Erişim Adresi: https://franceintheus.org/spip.php?article4093. Erişim Tarihi: 10.12.2020.

Embassy of France in Washington, D.C. (2010). Statement by Bernard Kouchner, Minister of Foreign and European Affairs. Erişim Adresi: https://franceintheus.org/spip.php?article1741. Erişim Tarihi: 10.12.2020. 
Embassy of France in Washington, D.C. (2019). Official Speeches and Statements. Erişim Adresi: https://franceintheus.org/spip.php?article9499. Erişim Tarihi: 10.12.2020.

Embassy of France in Washington, D.C. (2019). Official Speeches and Statements. Erişim Adresi: https://franceintheus.org/spip.php?article9386. Erişim Tarihi: 10.12.2020.

Embassy of the People's Republic of China in the Hellenic Republic. (2012). Foreign Ministry Spokesperson Liu Weimin's Regular Press Conference. Erişim Adresi:

http://gr.chinaembassy.org/eng/fyrth/t904275. htm. Erişim Tarihi: 10.12.2020.

European Commission. (2012). 3199th Council meeting Foreign Affairs Brussels. Erişim Adresi: https://ec.europa.eu/commission/presscorner/detail/en/PRES 1246 7. Erişim Tarihi: 10.12.2020.

Executive Order 13572. (2011). Blocking Property of Certain Persons With Respect to Human Rights Abuses in Syria, April 29, 2011. Presidential Document 78(85), 03.05.2011.

Executive Order 13573. (2011). Blocking Property of Senior Officials of the Government of Syria, May 18, 2011. Presidential Document 76(98), 20.05.2011.

Executive Order 13582. (2011). Blocking Property of the Government of Syria and Prohibiting Certain Transactions with Respect to Syria, August 17, 2011. Presidential Document 76(162), 22.08.2011.

Executive Order 13606. (2012). Blocking the Property and Suspending Entry Into the United States of Certain Persons With Respect to Grave Human Rights Abuses by the Governments of Iran and Syria via Information Technology, April 22, 2012. Presidential Document 77(79), 24.04.2012.

Foreign \& Commonwealth Office. (2010). Foreign Office Minister Expresses Concern over Human Rights in Syria. Erişim Adresi: https://www.gov.uk/government/news/foreign-office-ministerexpresses-concern-over-human-rights-in-syria. Erişim Tarihi: 10.12.2020.

Foreign \& Commonwealth Office. (2011). Foreign Office Minister Alistair Burt Expresses Concern at Ongoing Violence in Syria. Erişim 
Adresi: $\quad$ https://www.gov.uk/government/news/foreign-officeminister-alistair-burt-expresses-concern-at-ongoing-violence-in-syria. Erişim Tarihi: 10.12.2020.

Foreign \& Commonwealth Office. (2011). Foreign Office Minister Meets Syrian National Council Members. Erişim Adresi: https://www.gov.uk/government/news/foreign-office-minister-meetssyrian-national-council-members. Erişim Tarihi: 10.12.2020.

Foreign \& Commonwealth Office. (2012). British Diplomatic Staff in Syria Withdrawn. Erişim Adresi: https://www.gov.uk/government/news/british-diplomatic-staff-insyria-withdrawn. Erişim Tarihi: 10.12.2020.

Foreign \& Commonwealth Office. (2012). Foreign Secretary Statement on Gaza, the Middle East Peace Process and Syria. Erişim Adresi: https://www.gov.uk/government/news/foreign-secretary-statementon-gaza-the-middle-east-peace-process-and-syria. Erişim Tarihi: 10.12.2020.

Foreign \& Commonwealth Office. (2013). UK Announces Increased Assistance for Syria Crisis. Erişim Adresi: https://www.gov.uk/government/news/uk-announces-increasedassistance-for-syria-crisis. Erişim Tarihi: 10.12.2020.

Foreign \& Commonwealth Office. (2014). Gifting of Equipment to Syria. Erişim Adresi: https://www.gov.uk/government/speeches/gifting-ofequipment-to-syria--2. Erişim Tarihi: 10.12.2020.

Foreign \& Commonwealth Office. (2019). Syria: Foreign Secretary Condemns Recent Violence in Idlib Province. Erişim Adresi: https://www.gov.uk/government/news/syria-foreign-secretarycondemns-recent-violence-in-idlib-province. Erişim Tarihi: 10.12.2020 Foreign and Commonwealth Office. (2011). Joint UK, French and German statement on Syria. Erişim Adresi: https://www.gov.uk/government/news/joint-uk-french-and-germanstatement-on-syria. Erişim Tarihi: 10.12.2020.

Francis, E. (2017). U.S.-Russian Ceasefire Deal Holding in Southwest Syria, Reuters. Erişim Adresi: https://www.reuters.com/article/usmideast-crisis-syria-idUSKBN19U08D. Erişim Tarihi: 10.12.2020.

Gordon, M. R. \& Schmitt, E. (2013). Russia Sends More Advanced Missiles to Aid Assad in Syria, New York Times. Erişim Adresi: http://www. nytimes.com/2013/05/17/world/middleeast/russia- 
provides-syria-with-advanced-missiles.html.

Erişim

Tarihi: 10.12.2020.

Hubbard, B. \& Sanger, D. E. (2016). Russia, Iran and Turkey Meet for Syria Talks, Excluding U.S., New York Times. Erişim Adresi: https://www.nytimes.com/2016/12/20/world/middleeast/russia-iranand-turkey-meet-for-syria-talks-excluding-us.html. Erişim Tarihi: 10.12.2020.

Jennifer, C. \& Casagrande, G. (2015). Syrian Opposition Guide. Institute for the Study of War, 1-45.

Lister, C. (2016). The Free Syrian Army: A Decentralized Insurgent Brand. Brookings Institution 26, 1-40.

MacFarquhar, N. (2012). Western Nations, Protesting Killings, Expel Syrian Envoys, New York Times. Erişim Adresi: https://www.nytimes.com/2012/05/30/world/middleeast/kofi-annanmeets-with-bashar-al-assad.html?ref=middleeast. Erişim Tarihi: 10.12.2020.

Ministry of Foreign Affairs of the People's Rebuplic of China. (2019). Foreign Ministry Spokesperson Geng Shuang's Regular Press Conference.

https://www.fmprc.gov.cn/mfa eng/xwfw 665399/s2510 665401/25 11 665403/t1727131.shtml. Erişim Tarihi: 10.12.2020.

Ministry of Foreign Affairs of the People's Rebuplic of China. (2014). Foreign Ministry Spokesperson Hong Lei's Remarks on the UN Security Council's Vote on the Draft Resolution to Refer the Situation in Syria to the International Criminal Court. Erişim Adresi: https://www.fmprc.gov.cn/mfa eng/xwfw 665399/s2510 665401/25 35 665405/t1158923.shtml. Erişim Tarihi: 10.12.2020.

Ministry of Foreign Affairs of the People's Republic of China. (2012). Foreign Ministry Spokesperson Liu Weimin's Regular Press Conference. Erişim Adresi: https://www.fmprc.gov.cn/mfa eng/xwfw 665399/s2510 665401/25 11 665403/t923058.shtml. Erişim Tarihi: 10.12.2020.

Ministry of Foreign Affairs of the People's Republic of China. (2012). Foreign Ministry Spokesperson Qin Gang's Remarks on Syrian President's Special Envoy's Visit to China. Erişim Adresi: https://www.fmprc.gov.cn/mfa eng/xwfw 665399/s2510 665401/25 35 665405/t960727.shtml. Erişim Tarihi: 10.12.2020. 
Ministry of Foreign Affairs of the People's Republic of China. (2016). Statement by Ambassador WU Haitao at the Security Council After Voting on the Draft Resolution on Syria. Erişim Adresi: https://www.fmprc.gov.cn/mfa eng/wjb 663304/zwjg 665342/zwbd 665378/t1429865.shtml. Erişim Tarihi: 10.12.2020.

Miş, N. (2014). Suriye 2012. (Der.). İnat, K. \& Ataman, M. Ortadoğu Yıllığı 2012 içinde (217-253). İstanbul: Açılım Kitap.

Miş, N. \& Özdemir, Ö. B. (2015). Suriye 2014. (Der.). İnat, K. \& Ataman, M. Ortadoğu Yıllığı 2014 içinde (167-194). İstanbul: Açılım Kitap.

National Coalition for Syrian Revolution and Opposition Forces. (t.y.). Erişim Adresi: https://en.etilaf.org/Erişim Tarihi: 10.12.2020.

Permanent Mission of the Russian Federation to the United Nations. (2017). Statement by Mr.Vladimir Safronkov, Deputy Permanent Representative of the Russian Federation to the United Nations, at the Security Council on the Situation in the Middle East. Erişim Adresi: http://russiaun.ru/en/news/sc fsr. Erişim Tarihi: 10.12.2020.

President of Russia. (2011) Interview by Dmitry Medvedev. Erişim Adresi: http://en.kremlin.ru/events/president/news/12204. Erişim Tarihi: 10.12.2020.

Radio Free Europe. (2016). Russia Confirms Deployment of S-300 Air Defense Missiles To Syria. Erişim Adresi: https://www.rferl.org/a/russia-syria-s-300deployment/28031744.html. Erişim Tarihi: 10.12.2020.

Radio Free Europe. (2017). Putin Signs Law Allowing Expansion of Russian Naval Facility in Syria. Erişim Adresi: https://www.rferl.org/a/putin-signs-law-syria-tartus-navalfacility/28946167.html. Erişim Tarihi: 10.12.2020.

Reuters. (2012). China says Solution to Syria Crisis Must be Led by Its People. Erişim Adresi: https://uk.reuters.com/article/uk-chinasyria/china-says-solution-to-syria-crisis-must-be-led-by-its-peopleidUKBRE88G0JF20120917. Erişim Tarihi: 10.12.2020.

Sarı Ertem, H. (2018). Surrogate Warfare in Syria and the Pitfalls of Diverging US Attitudes Toward ISIS and PYD/YPG. (Der.). Oktav, Ö. Z., Parlar Dal, E. \& Kurşun, A. M. Violent Non-state Actors and the Syrian Civil War: The ISIS and YPG Cases içinde (129-148). Cham: Springer. 
Stanford University. (t.y.). Mapping Militant Organizations, Erişim Adresi: $\quad$ http://web.stanford.edu/group/mappingmilitants/cgibin/maps/view/syria Erişim Tarihi: 10.12.2020.

Syrian National Council. (t.y.). Information on the SNC. Erişim Adresi: http://syriancouncil.org. Erişim Tarihi: 10.12.2020.

Taşdemir, F. (2016). Suriye İç Savaşı'na Üçüncü Devletlerin Müdahalesi ve Uluslararası Hukuk. (Der.). Taşdemir, F. Suriye, Çatışma ve Uluslararası Hukuk, içinde (157-182). Ankara: Nobel Yayıncılık.

The Council of the European Union (2011). Council Decision 2011/273/CFSP of 9 May 2011 Concerning Restrictive Measures against Syria. Official Journal of the European Union 54, L. 121, 10.05.2011.

The Council of the European Union. (2013). Council Decision 2013/255/CFSP of 31 May 2013 Concerning Restrictive Measures against Syria. Official Journal of the European Union 14(147), 01.06.2013.

The Council of the European Union. (2013). Council Eases Sanctions against Syria to Support Opposition And Civilians. 8611/13, Presse 155. 22.04.2013.

The Council of the European Union. (2019). Council Implementing Decision (CFSP) 2019/87 of 21 January 2019: Implementing Decision 2013/255/CFSP Concerning Restrictive Measures against Syria. Official Journal of the European Union 18(13), 21.01.2019.

The Ministry of Foreign Affairs of the Russian Federation. (2011) Bloomberg Full Transcript Of Sergey Lavrov Interview. Erişim Adresi: https://www. mid.ru/en/web/guest/vistupleniya ministra/-

Lasset publisher/MCZ7HQuMdqBY/content/id/204754. Erişim Tarihi: 10.12.2020.

The Ministry of Foreign Affairs of the Russian Federation. (2015). Foreign Minister Sergey Lavrov's statement and answers to media questions at a joint news conference following tripartite consultations with Sudanese Foreign Minister Ibrahim Ghandour and South Sudanese Foreign Affairs and International Cooperation Minister Benjamin Barnaba, Moscow. Erişim Adresi: https://www.mid.ru/en/web/guest/meropriyatiya s uchastiem minis tra/-/asset publisher/xK1BhB2bUjd3/content/id/1741028 Erişim Tarihi: 10.12.2020. 
The Ministry of Foreign Affairs of the Russian Federation. (2015). Press Release on Foreign Minister Sergey Lavrov's talks with Syrian Deputy Prime Minister and Minister of Foreign Affairs and Expatriates Walid Muallem. Erişim Adresi: https://www.mid.ru/en/web/guest/foreign policy/international safet y/conflicts/-/asset publisher/xIEMTQ30vzcA/content/id/1512837.

Erişim Tarihi: 10.12.2020.

The Ministry of Foreign Affairs of the Russian Federation. (2015). Remarks by Foreign Minister Sergey Lavrov at The Start of the Meeting with A Group of Representatives of the Syrian Opposition and the Syrian Government, Moscow. Erişim Adresi: https://www.mid.ru/en/web/guest/foreign policy/news/Lasset publisher/cKNonkJE02Bw/content/id/916460. Erişim Tarihi: 10.12.2020.

The Ministry of Foreign Affairs of the Russian Federation. (2016). Foreign Ministry Statement in Connection with Russia's Veto of the French-Proposed UN Security Council Draft Resolution on Syria. Erişim Adresi: http://special.mid.ru/en/web/guest/maps/sy/Lasset publisher/9fcjSOwMERcf/content/id/2494622. Erişim Tarihi: 10.12.2020.

The Ministry of Foreign Affairs of the Russian Federation. (2019). Comment by the Information and Press Department on the Mechanism for the Cross-Border Delivery of Humanitarian Aid to the Syrian Arab Republic. Erişim

Adresi: https://www.mid.ru/en/web/guest/foreign policy/international safet y/conflicts/-/asset publisher/xIEMTQ30vzcA/content/id/3975548

Erişim Tarihi: 10.12.2020.

The State Council: The People's Republic of China. (2015). More Aid From China Set for Syria. Erişim Adresi: http://english.www.gov.cn/news/international exchanges/2015/12/2 5/content 281475260338929.htm. Erişim Tarihi: 10.12.2020.

The State Council: The People's Republic of China. (2017). China to Donate Humanitarian Aid to Syria Worth $\$ 16 \mathrm{~m}$. Erişim Adresi: http://english.www.gov.cn/news/international exchanges/2017/02/0 6/content 281475560526100.htm. Erişim Tarihi: 10.12.2020.

The State Council: The People's Republic of China. (2018). State Councilor Says China Willing to Help Syrian Development. Erişim Adresi: 
http://english.www.gov.cn/state council/state councilors/2018/09/2 8/content 281476322288948. htm. Erişim Tarihi: 10.12.2020.

The State Council: The People's Republic of China. (2020). Chinese, Russian Fms Discuss Gulf Tensions, Cooperation at UN Security Council over Phone. Erişim Adresi: http://english.www.gov.cn/statecouncil/wangyi/202001/05/content WS5e1132c8c6d0cee5d284b268. html. Erişim Tarihi: 10.12.2020.

The White House. (2011). Statement by President Obama on the Situation in Syria. Erişim Adresi: https://obamawhitehouse.archives.gov/the-pressoffice/2011/08/18/statement-president-obama-situation-syria. Erişim Tarihi: 10.12.2020.

U.S. Department of State. Secretary Michael R. Pompeo and Russian Foreign Minister Sergey Lavrov at a Press Availability. Erişim Adresi: https://www.state.gov/secretary-michael-r-pompeo-and-russianforeign-minister-sergey-lavrov-at-a-press-availability/. Erişim Tarihi: 10.12.2020.

U.S. Department of State. (2011). Violence in Syria. Erişim Adresi: https://2009-2017.state.gov/r/pa/prs/ps/2011/03/158894.htm.

Erişim Tarihi: 10.12.2020.

U.S. Department of State. (2012). Suspending Embassy Operations in Syria. U.S. Department of State. Erişim Adresi: https://20092017.state.gov/r/pa/prs/ps/2012/02/183352.htm. Erişim Tarihi: 10.12.2020.

U.S. Department of State. (2013). Syria: U.S. Nonlethal Assistance. Erişim Adresi:

2017.state.gov/r/pa/prs/ps/2013/218654.htm. Erişim Tarihi: 10.12.2020.

U.S. Department of State. (2015). Additional Assistance for the Syrian Opposition. Erişim Adresi: https://20092017.state.gov/r/pa/prs/ps/2015/10/249033.htm. Erişim Tarihi: 10.12.2020.

U.S. Department of State. (2019). Russian Federation's and China's Veto of UNSCR 2449 Aid to Syrian Refugees. Erişim Adresi: https://www.state.gov/russian-federations-and-chinas-veto-of-unscr2449-aid-to-syrian-refugees/. Erişim Tarihi: 10.12.2020. 
U.S. Department of the Treasury. (2013). Syria Sanctions Program. 02.08.2013.

U.S. Department of the Treasury. (2019). Syria Sanctions. Erişim Adresi:

https://www.treasury.gov/resourcecenter/sanctions/programs/pages/syria.aspx. Erişim Tarihi: 10.12.2020.

U.S. Department of the Treasury. (2019). Sanctions Risks Related to Petroleum Shipments Involving Iran and Syria. 25.03.2019.

Ulutaş, U. (2011). The Syrian Opposition in the Making: Capabilities and Limits. Insight Turkey 13(3), 87-106.

Ulutaş, U. (2016). The Syrian Political Opposition: What Went Wrong?. Insight Turkey 18(2), 31-39.

United Nations General Assembly. (2012). Final Communiqué of the Action Group for Syria. A/66/865-S/2012/522. 30.07.2012.

United Nations Security Council. (2011). Draft Resolution S/2011/612. Erişim

http://www.un.org/ga/search/view doc.asp?symbol=S/2011/612.

Erişim Tarihi: 10.12.2020.

United Nations Security Council. (2011). Security Council Fails to Adopt Draft Resolution Condemning Syria's Crackdown on Anti-Government Protestors, Owing to Veto by Russian Federation, China SC/10403. Erişim

Adresi: http://www.un.org/press/en/2011/sc10403.doc.htm. Erişim Tarihi: 10.12.2020.

United Nations Security Council. (2012). Draft Resolution S/2012/538. Erişim Adresi: http://www.un.org/ga/search/view doc.asp?symbol=S/2011/612.

Erişim Tarihi: 10.12.2020.

United Nations Security Council. (2012). Security Council Fails to Adopt Draft Resolution on Syria That Would Have Threatened Sanctions, Due to Negative Votes of China, Russian Federation SC/10714. Erişim Adresi: http://www.un.org/press/en/2012/sc10714.doc.htm. Erişim Tarihi: 10.12.2020.

United Nations Security Council. (2013). Resolution 2118. 27.09.2013. United Nations Security Council. (2014). Referral of Syria to International Criminal Court Fails as Negative Votes Prevent Security Council from Adopting Draft Resolution SC/11407. Erişim Adresi: 
https://www.un.org/press/en/2014/sc11407.doc.htm. Erişim Tarihi: 10.12.2020.

United Nations Security Council. (2014). Resolution 2139. 22.02.2014. United Nations Security Council. (2014). Resolution 2165. 14.07.2014. United Nations Security Council. (2014). Resolution 2170. 15.08.2014. United Nations Security Council. (2016). Resolution 2336. 31.12.2016. United Nations Security Council. (2016). Security Council Supports Russian Federation-Turkey Efforts to End Violence in Syria, Jump-start Political Process, Adopting Resolution 2336 (2016) SC/12663. Erişim Adresi: http://www.un.org/press/en/2012/sc10536.doc.htm. Erişim Tarihi: 10.12.2020.

Van de Graaf, T. (2013). The Oil Weapon Reversed? Sanctions Against Iran and US-EU Structural Power. Middle East Policy 20(3). 145-163. 